Wyższa Szkoła Nauk Humanistycznych i Dziennikarstwa, Poznań

\title{
Realizacja programu reprywatyzacji w Republice Czeskiej i na Węgrzech po roku 1989
}

Droces reprywatyzacji jest ściśle powiązany z kontekstem denacjonalizacyjnym prywatyzacji. Problem ten występuje, gdy aktualnie prywatyzowana własność państwowa uprzednio podlegała nacjonalizacji. Argumenty na rzecz odtworzenia praw własności dawnych właścicieli zderzają się i podważają wcześniejsze uzasadnienia nacjonalizacji zarówno o charakterze klasowym, jak i narodowym. Powstaje też problem stworzenia procedury reprywatyzacyjnej, mającej rozstrzygnąć, które z roszczeń powinny zostać uwzględnione i w jakiej formie należy tego dokonać ${ }^{1}$. We wszystkich opisywanych krajach z mniejszym lub większym sukcesem próbowano zmierzyć się z problemem zwrotu majątku byłym właścicielom. Wszędzie też napotykano na podobne problemy, wykluczające praktycznie powrót do pierwotnego stanu rzeczy, np. na Węgrzech, w przypadku ziemi, wiązało się to wycofaniem po II wojnie światowej z produkcji rolnej ogromnych obszarów. W każdym z krajów większość dużych zakładów przemysłowych uległa rozbudowie - w okresie powojennym zrealizowano wiele inwestycji państwowych zmieniających całkowicie charakter przedsiębiorstw. Jednocześnie sprzedaż mieszkań, które przeszły kiedyś na własność państwa, odbywała się na ogromną skalę. Jak zauważa T. Sepsey: „Tak można by wyliczać te wszystkie trudności w nieskończoność, które nawet przy dobrym stanie gospodarki, uniemożliwiały wydanie rekompensat w stanie pierwotnym",2. Zwłaszcza, że trudno było znaleźć odpowiedź na pytanie, czym jest sprawiedliwość po tylu latach bezprawia? Szczególnie skomplikowana była w tym względzie właśnie sytuacja Polski. Jednak to nasi południowi sąsiedzi mieli ważny powód, by szybko uporać się z reprywatyzacją. W ich krajach nacjonali-

1 A. Suwalski, Uwłaszczenie obywateli jako element polskiej prywatyzacji, Poznań 2004, s. 59.

2 T. Sepsey, Krótka historia procesu odszkodowań, w: Janusowe oblicze transformacji na Wegrzech, red. M. Schmidt, L. Gy. Toth, Warszawa 2001, s. 357. 
zacja ziemi była jedynie wstępem do pełnej kolektywizacji rolnictwa. Po 1989 roku Czechosłowacja czy Węgry musiały coś zrobić z majątkiem pegeerów i kołchozów. Rozwiązanie wydawało się oczywiste: należy zwrócić go byłym właścicielom - chłopom, których komunizm chciał przekształcić w robotników rolnych. W Polsce natomiast przetrwały prywatne gospodarstwa rolne, problem reprywatyzacji nie wydawał się więc palący. Z drugiej zaś strony, w ramach reformy rolnej na podstawie dekretu PKWN ziemię otrzymało około 400 tys. rodzin chłopskich. Odebranie tej ziemi, głównie ze względu na siłę tego elektoratu, nie leżało w interesie żadnej liczącej się partii politycznej.

W artykule przedstawione zostały czechosłowackie i węgierskie pomysły na realizację programu reprywatyzacji, w podsumowaniu zostały one skonfrontowane $\mathrm{z}$ polskimi programami reprywatyzacyjnymi.

\section{Czechosłowacja (Czechy, Słowacja)}

Jak zauważa A. Wołek: „Zestawienie węgierskich ustaw rekompensacyjnych z czechosłowacką polityką reprywatyzacji (restytucji mienia) pokazuje, jak różne mogą być reguły życia publicznego obejmowane potocznie tą samą nazwą, w tym wypadku terminem reprywatyzacja"3. O ile węgierska akcja rekompensacyjna była przede wszystkim krokiem wprzód i miała przyczynić się do wspomnianej już wcześniej budowy nowej klasy średniej, o tyle czeska reprywatyzacja była przede wszystkim próbą odwrócenia negatywnych skutków polityki komunistów w sferze własności prywatnej, a zatem podobnie jak prywatyzacja kuponowa miała służyć pełnemu i jak najszybszemu zerwaniu z poprzednim reżimem. Różnica w pojmowaniu zadań i celów stawianych przed reprywatyzacją w obu krajach wiąże się również w prosty sposób ze stanem i strukturą gospodarki z jaką oba państwa rozpoczęły transformację w 1989 roku. Najistotniejszą kwestia, o czym szerzej była mowa w poprzednich rozdziałach, było prawie 100\% upaństwowienie gospodarki w Czechach, podczas gdy na Węgrzech już w 1989 roku istniał, zajmujący kilkanaście procent PKB sektor prywatny. Stąd na Węgrzech reprywatyzacja nigdy nie była traktowana przede wszystkim jako sposób na szybkie zerwanie z komunizmem.

Oczywiście czescy ustawodawcy zdawali sobie sprawę, że naprawienie krzywd wyrządzonych przez komunistów nigdy nie będzie możliwe,

3 A. Wołek, Demokracja nieformalna, Warszawa 2004, s. 200. 
jednak ich głównym celem było zadośćuczynienie krzywdom z okresu dawnego reżimu oraz odbudowanie w nowym ładzie demokratycznym pozycji własności prywatnej jako „uprawnienia nienaruszalnego"

W programach wyborczych głównych partii, zwłaszcza ODS, znajdowało się mocne poparcie dla idei reprywatyzacji. W 1996 r. ODS zapisała: „Reformę czeskiego rolnictwa zapoczątkowano od szybkich zmian, które były częścią składową transformacji systemowej; czyli od liberalizacji cen, likwidacji centralnego planowania, stworzenia warunków rynkowych i ograniczenia ingerencji państwa. Podstawowym narzędziem zmian systemowych był szeroko zakrojony proces restytucji (reprywatyzacji) i zapoczątkowanie restrukturyzacji i prywatyzacji przedsiębiorstw rolnych. Reprywatyzacja i prywatyzacja miały służyć przywróceniu w rolnictwie decydującego impulsu rozwojowego; własności prywatnej jako źródła aktywności, kreatywności, gospodarności i odpowiedzialności", Dla partii V. Klausa szybkie dokończenie reprywatyzacji w rolnictwie miało być istotnym warunkiem dokończenia procesu prywatyzacji przedsiębiorstw rolnych, co w konsekwencji miało przynieść likwidację nieefektywnych podmiotów i zwiększenie prosperity przedsiębiorstw zdolnych do rozwoju. Także w kolejnym dokumencie programowym z 1998 roku deklarowano: „definitywne zakończenie aktywności reprywatyzacyjnej przy przestrzeganiu wymogów sprawiedliwości i stabilności stosunków własności” ${ }^{\prime}$. Partią, która bardzo krytycznie wypowiadała się na temat reprywatyzacji, byli komuniści, pisząc, iż należy: „Zatrzymać prywatyzację i sprawdzić kontrowersyjne decyzje prywatyzacyjne. Zakończyć reprywatyzację i przeprowadzić rewizję wszelkich dużych decyzji reprywatyzacyjnych na rzecz Kościoła katolickiego i na rzecz osób z problematycznymi roszczeniami reprywatyzacyjnymi. Nie chcemy powszechnej nacjonalizacji i niezgodnej z prawem ingerencji w stosunki własności, jednak szanujemy tylko absolutnie legalne roszczenia. Bezpieczeństwo zagwarantujemy wszystkim, którzy zdobyli swój majątek uczciwie"7.

Zwrot majątków został w większości przeprowadzony jeszcze przed rozpadem Czechosłowacji. Reprywatyzację rozpoczęto tam w latach 1990-1991 na podstawie czterech ustaw. W Czechach z reprywatyzacji wyłączono Niemców sudeckich, na Słowacji emigrantów mieszkających

4 Ibidem, s. 200.

5 Pokazaliśmy, że potrafimy, Program wyborczy ODS, 1996.

6 Przyszłość nie obciażona dlugami, Program ODS, 1998.

7 Naprzód ku socjalizmowi. Nie wstecz!, Program wyborczy KSCM, 1998. 
za granicą. Rzecz jasna, nie obeszło się bez kontrowersji, co wpływało także na niechęć Czechów do zagranicznych, zwłaszcza niemieckich inwestorów. Ostro protestowało ziomkostwo Niemców Sudeckich. Ci ludzie byli przed wojną obywatelami czechosłowackimi; w 1945 roku wypędzono ich i skonfiskowano majątki w odwecie za to, że w 1938 roku poparli przyłączenie Sudetów do Trzeciej Rzeszy. Przez wiele lat brak było również zgody politycznej na reprywatyzację majątków kościelnych. Walczyła o to konsekwentnie KDU-CSL, której elektorat wywodził się w większości z katolickich Moraw. Sprzeciw, wspierany głosami opozycji komunistycznej i socjaldemokratycznej, zgłaszała głownie ODS. Ludowcy grozili rozbiciem koalicji, jeśli ODS, zamiast oddać majątki Kościołowi, sprywatyzuje je. Ostatecznie problem został rozwiązany dopiero po zmianie rządów w 1996 roku $^{8}$.

Początkowo wydawało się, że czechosłowacka polityka w sprawie reprywatyzacji nie będzie różniła się od rozwiązań przyjętych na Węgrzech. Projekty, które zaczęto przygotowywać w czasach rządów porozumienia narodowego, zakładały wypłatę odszkodowań za znacjonalizowane mienie w gotówce i w papierach wartościowych gwarantowanych przez państwo. Jeszcze jesienią 1990 roku, gdy projekty ustaw reprywatyzacyjnych zostały wniesione przez nowy rząd, zakładały one właśnie rekompensatę pełnej wartości utraconego mienia. Jednak wbrew opinii większości polityków tworzących rząd, w tym samego V. Klausa, którzy przekonywali o wyższości prywatyzacji nad reprywatyzacją, posłowie OF wraz z posłami CSL zdołali przekonać większość parlamentu do poparcia zasady zwrotu mienia w naturze ${ }^{9}$. Przyjęto zasadę możliwie szerokiego stosowania zwrotu mienia w naturze; rekompensaty płacono jedynie w wyjątkowych przypadkach. Uchwalone w październiku 1990 roku ustawy: o restytucji i pozasądowej rehabilitacji z lutego 1991 roku, przewidywały zwrot w naturze mieszkań i nieruchomości komercyjnych utraconych na skutek prześladowań politycznych w latach 1948-1989 w wyniku dekretów nacjonalizacyjnych, ale także decyzji administracyjnych i wymuszonych umów cywilnoprawnych. I jak zauważa A. Wołek: „Ustawa nie rozwiązywała wszystkich problemów związanych z zadośćuczynieniem za krzywdy wyrządzone przez dawny reżim"10, to jednak stała się prawdziwym fundamentem budowy nowego ładu demokratycznego w Cze-

8 B. Sierszuła, Jak zostać dostrzeżonym, „Rzeczpospolita” z 15.01.1996.

A. Wołek, op. cit., s. 200.

${ }^{10}$ Ibidem, s. 201. 
chosłowacji, gdzie ponad 100 tys. dawnych właścicieli odzyskało swoje mienie.

\section{Węgry}

Sprawa reprywatyzacji miała istotne miejsce prawie we wszystkich analizowanych programach wyborczych partii węgierskich, zwłaszcza w początkowym okresie transformacji. W dokumencie FKgP z 1993 roku podkreślano, iż: „Należy przywrócić święte prawo własności i w związku z tym należy jak najszybciej przeprowadzić reprywatyzację [...] Uważamy, że nikt, kto stoi na szczycie zrabowanych rzeczy, nie może głosić zasady świętości własności prywatnej. Za najlepszy sposób ochrony własności prywatnej uznajemy ogłoszenie zasady reprywatyzacji, czyli wszędzie tam, gdzie jest to jeszcze możliwe, przeprowadzalibyśmy reprywatyzacjęe"11. Było to rozwinięcie założeń z 1990 roku, gdzie w „Programie odrodzenia narodowego" partia ta zapisała: „Zabraną ziemię należy zwrócić chłopom, względnie ich prawnym spadkobiercom - o ile się tego domagają" 12 . W dokumencie tym bardzo dokładnie określono również założenia samego programu reprywatyzacji ${ }^{13}$. W materiałach wyborczych FIDE-

11 Nasza przeszłość, Nasza teraźniejszość, Nasza przyszłość, Program Niezależnej Partii Drobnych Właścicieli, 1993.

12 Program odrodzenia narodowego, Program Niezależnej Partii Drobnych Właścicieli, 1990.

${ }_{13}$ Powinna być szybka, sprawiedliwa i rozciaggająca się na całą gospodarkę. Jednostki państwowe należy przekazać zgodnie z obecną wartością w ręce pracowników w taki sposób, że:

a) przekazanie obejmie nie cały majątek, ale wyniesie do $76 \%$;

b) przekazanie nie będzie bezpłatne, ale:

- pracownik danego przedsiębiorstwa będzie mógł kupić papiery wartościowe o wartości nominalnej $10-15 \%$,

- inni pracownicy będą mogli kupić papiery wartościowe o wartości nominalnej 20-30\%,

- każdy inny obywatel Węgier będzie mógł kupić papiery wartościowe o wartości nominalnej $50 \%$,

- obcokrajowcy mogą kupić papiery wartościowe o wartości nominalnej;

c) pozostałe $24 \%$ będzie należało do państwa. Państwo będzie mogło podjąć następujące kroki: zatrzymać majątek w celu uzyskania dywidendy lub wystawić go na sprzedaż, tym razem po cenach rynkowych;

d) nowi właściciele mogą wystawiać na sprzedaż zakupione papiery wartościowe według uznania. Jedynym warunkiem jest to, aby przez pierwsze 5 lat od rozpo- 
SZ-u brak odniesień do reprywatyzacji. Zapis o konieczności dokończenia reprywatyzacji znalazł się natomiast w programie MSZP z 1994 roku, stwierdzono tam, iż: „Na ogół nie akceptujemy reprywatyzacji, ale mając na uwadze już dokonaną prywatyzację, odszkodowania i efekty zwracania majątku, gwarantujemy bezpieczeństwo właścicielom. Szybkie zakończenie i ostateczne zamknięcie procesu wypłacania odszkodowań uznajemy za najważniejszy warunek bezpieczeństwa własności. Potępiamy dyskryminujący, wynikający z lojalności politycznej, stronniczy lub manipulacyjny rozdział majątku"14. Również politycy MDF dopuszczali reprywatyzację jako jedną z preferowanych form przekształceń własnościowych. Miała być ona realizowana czterema sposobami:

- na podstawie rządowego programu prywatyzacyjnego;

- w drodze Planu Pracowniczej Własności Akcji (ESOP) zakupu akcji;

- przydziału części akcji przedsiębiorstw państwowych dla fundacji, samorządów lokalnych i zakładów ubezpieczeń społecznych zamiast wsparcia budżetowego;

- w rolnictwie powrót ziemi do pierwotnych właścicieli;

- ewentualnie w drodze wymiany za część zewnętrznego zadłużenia (debt-equity swap).

Zaznaczając jednocześnie, iż proces ten nie może być motywowany względami ideologicznymi. Podsumowując swoje rządy, Węgierskie Forum Demokratyczne podkreślało: ,przeprowadziliśmy proces przyznawania rekompensat, który objął ponad milion osób, z czego do tej pory 250 tysięcy osób otrzymało ziemię"15.

Wchodząc do koalicyjnego rządu J. Antalla, Drobni Posiadacze stawiali praktycznie tylko jeden postulat - reprywatyzację, która jednak pozostawała w wyraźnej sprzeczności z pomysłami MDF na utworzenie nowoczesnej klasy średniej, co miało nastąpić dzięki politycznie kontrolowanej prywatyzacji. Antall zdawał sobie sprawę z faktu, iż nieodpłatne przekazanie gruntów ornych około milionowi obywateli, byłoby drastycz-

częcia prywatyzacji udział zagraniczny nie przekroczył 49\%. Za wyjątkiem, jeżeli w ciaggu tych pięciu lat Parlament nie zadecyduje inaczej;

e) jednostki chcące oddzielić się od centrum, mogą to uczynić swobodnie, w takiej sytuacji oddzielenie następuje po przekazaniu w prywatne ręce.

Przekazanie w ręce prywatne nie będzie miało powszechnego zakresu, ponieważ niektóre jednostki figurujące na liście zatwierdzonej przez Parlament pozostaną całkowicie państwowe niektóre przez krótszy okres, niektóre na dłużej.

${ }_{14}$ Wyzwania $i$ odpowiedzi, Program wyborczy MSZP 1994-1998.

15 Pewne kroki, Spokojna przyszłość!, Program MDF, 1994. 
nym zerwaniem nie tylko z polityką okresu komunistycznego, ale i z porządkiem społecznym powstałym po nacjonalizacji. MDF, który w kampanii promował się jako „siła spokoju”, stroniąca od radykalizmu antykomunistów, był jak najdalszy od zgody na taki eksperyment ${ }^{16}$.

Premier Antall zastosował więc wybieg w postaci zwrócenia się do Sądu Konstytucyjnego z prośbą o „opinię doradczą”, jaka forma reprywatyzacji jest dopuszczalna konstytucyjnie. Opinia taka, wydana na podstawie ustawy o „Sądzie Konstytucyjnym”, choć tylko doradcza, była wiążąca dla późniejszego orzecznictwa Sądu i w tym sensie wyznaczała pole manewru dla przyszłych prac ustawodawczych. Odrzucenie radykalnych pomysłów reprywatyzacyjnych, którego spodziewał się Antall, pozwoliłoby mu zachować głosy FKgP i realizować własny program prywatyzacji. W pytaniu premiera określono prywatyzację jako główny cel polityki rządu, w ramach której byli właściciele mieli otrzymać częściową rekompensatę za utracony majątek. Wyjątkiem od tej zasady miały być grunty orne, które byłyby zwracane w naturze dawnym właścicielom. Pytanie dotyczyło konstytucjonalności rozróżnienia dawnych właścicieli na podstawie rodzaju utraconej własności, a także możliwości odebrania rolniczym spółdzielniom produkcyjnym ziemi, którą uzyskały w ramach kolektywizacji ${ }^{17}$.

Od początku transformacji przygotowanie ustawy reprywatyzacyjnej i jej zapisy budziły wiele kontrowersji, głównie natury prawnej. Konsultacje z Sądem Konstytucyjnym spowodowały, że rząd zakończył prace nad swoim projektem ustawy o odszkodowaniach majątkowych. Rząd premiera Antalla, przygotowując ustawę o rekompensatach, wybrał z opinii Sądu to, czego potrzebował (dopuszczalność relatywnie swobodnego dysponowania majątkiem państwowym, przy jednoczesnym zakazie reprywatyzacji gruntów w naturze), nie zważając przy tym zbytnio na standardy wyznaczone przez Sąd.

W grudniu 1990 roku przedłożył parlamentowi projekt ustawy numer 1020 o częściowych odszkodowaniach bezprawnie poniesionych strat przez obywateli po 8 czerwca 1949 roku. Burzliwy charakter dyskusji parlamentarnej najlepiej obrazuje fakt, iż do projektu ustawy zgłoszono 415 poprawek, a 52 posłów poprosiło o wstępne zbadanie przez Trybunał Konstytucyjny poszczególnych zapisów ustawy, które uznawano za nie-

\footnotetext{
16 A. Wołek, op. cit., s. 196.

17 A. Wołek, op. cit., s. 196-197.
} 
zgodne $\mathrm{z}$ konstytucją ${ }^{18}$. Jedną z takich kwestii było rozwiązanie problemu tzw. spółdzielni (odpowiednik polskich PGR-ów), które w okresie niedemokratycznym zarządzały majątkiem ziemskim. Węgierska Partia Socjalistyczna chciała uchronić spółdzielnie od ciężaru odszkodowań, co więcej im także chciała je przyznać. MSZP domagała się przekazania bonów odszkodowawczych o wartości 80 miliardów forintów nie tylko byłym właścicielom, ale także wszystkim pracownikom. W debacie nad ustawą reprywatyzacyjnąjej zdecydowanym przeciwnikiem był FIDESZ, który wskazując na niepewną przyszłość węierskiej młodzieży, opowiadał się za przeznaczeniem pieniędzy na inne prorozwojowe cele. Pozostałe partie, głównie koalicyjne, były zwolennikami częściowej reprywatyzacji, choć ustawa rządowa budziła wiele kontrowersji również w szeregach $\mathrm{FKgP}$.

Parlament ostatecznie zatwierdził ustawę na posiedzeniu w dniu 6 maja 1991 roku. Ustawa o „Uregulowaniu stosunków własnościowych i częściowych odszkodowaniach własności bezprawnie odebranych obywatelom przez państwo” została opublikowana w „Monitorze Węgierskim" i weszła w życie w dniu 11 lipca 1991 roku. Jak zapisano w tym dokumencie, jego celem miała być naprawa szkód niesprawiedliwie wyrządzonych przez dawny reżim oraz uregulowanie kwestii własnościowych $^{19}$. Ustawa zawierała szczegółowe zasady rekompensat, jednakże odszkodowania były przyznawane za szkody powstałe na skutek przepisów prawnych uchwalonych dopiero po 8 czerwca 1949 roku, wymienionych w załączniku nr 2 do ustawy. Dlatego 7 kwietnia 1992 r. została uchwalona (weszła w życie 8 czerwca 1992 r.) tzw. II ustawa o odszkodowaniach. Była znacznie mniejszej objętości od aktu przyjętego w 1991 roku, ale regulowała nie tylko szkody powstałe na mocy przepisów prawnych z okresu 1 maja 1939-8 czerwca 1945, ale także na podstawie doświadczeń wynikających z realizacji pierwszej ustawy, uzupełniała przepisy prawne będące podstawą odszkodowań o różne sposoby wyliczania poniesionych szkód (innych niż gruntowe) ${ }^{20}$.

Pierwsza z ustaw reprywatyzacyjnych uprawniała do otrzymania bonów rekompensacyjnych proporcjonalnie do wartości utraconego majątku (w najniższym przedziale poszkodowani otrzymywali bony o wartości

18 T. Sepsey, op. cit., s. 358.

19 Ustawa o uregulowaniu stosunków własnościowych i częściowych rekompensatach za szkody wyrządzone własności obywateli (XXV/1991).

20 T. Sepsey, op. cit., s. 360-361. 
$100 \%$ utraconego majątku, w najwyższym tylko $10 \%$ ). Za bony można było nabywać grunty orne na otwartych aukcjach oraz płacić nimi za prywatyzowane przedsiębiorstwa i mieszkania pochodzące z zasobów państwowych i miejskich. Ustawa zobowiązywała także rolnicze spółdzielnie produkcyjne do przekazania połowy gruntów otrzymanych w ramach kolektywizacji na cele rekompensacyjne ${ }^{21}$. Takie prawo w bardzo sprytny sposób omijało pułapki, jakie na reprywatyzację zastawił Sąd Konstytucyjny. Budowaniu klasy średniej służyły przede wszystkim rekompensaty, a także częściowe zaspokojenie żądań osób reprezentowanych przez Partię Drobnych Posiadaczy.

Na podstawie I ustawy o odszkodowaniach złożono ponad 800 tys. wniosków, natomiast na podstawie II ustawy o odszkodowaniach, prawie 80 tys. Wiosną 1994 r. urzędy ds. odszkodowań zarejestrowały dodatkowo ponad 500 tys. tzw. wniosków uzupełniających. Rozpatrywaniem wszystkich złożonych dokumentów zajmował się, powołany na mocy ustawy z 1991 roku Krajowy Urząd ds. Regulacji Szkód i Odszkodowań. W efekcie do lata 1997 r. urzędy ds. odszkodowań przeprowadziły prawie 26 tys. licytacji. Podczas przetargów w ręce prywatne przeszły ziemie o wartości około 39 milionów złotej korony ${ }^{22}$. Mimo wielu nadużyć podczas licytacji i wymiany bonów reprywatyzacyjnych na ziemie, a także w okresie późniejszym (szybkie zbywanie ziemi bez przestrzegania minimum 5-letniego okresu jej użytkowania, co zapisane było w ustawie z 1991 roku), była to obok czeskiej najlepiej i najsprawniej przeprowadzona reprywatyzacja w krajach dokonujących po 1989 roku transformacji ustrojowej. Chociaż jak piszą sami Węgrzy: „W okresie przemian ustrojowych proces rekompensat znalazł się w centrum walki politycznej i to w dużej mierze może być wytłumaczeniem, dlaczego ta część procesu zadośćuczynienia udała się jedynie połowicznie"23.

Odszkodowania, które były znaczącą częścią procesu zmian ustrojowych, odegrały decydującą rolę w likwidacji własności społecznej. Wartość bonów wydanych na podstawie pierwszej ustawy reprywatyzacyjnej rząd węgierski oszacował na około 100 miliardów forintów, w przypadku drugiej ustawy było to 20 miliardów, natomiast wartość bonów wydanych osobom prześladowanym politycznie oszacowano na 50 miliardów forin-

21 A. Wołek, op. cit., s. 198.

22 Złota korona - tradycyjna węgierska jednostka oznaczająca wartość ziemi uprawnej na podstawie jej jakości i możliwości produkcyjnej.

23 T. Sepsey, op. cit., s. 371. 
tów. Do połowy 1997 r., kiedy proces reprywatyzacji został praktycznie zakończony, wydano ogółem bony o wartości nominalnej 135,3 miliarda forintów (w 1997 kurs forinta wahał się w granicach $1 \mathrm{zł}=60$ huf). Biorąc pod uwagę wielkość majątków przeznaczonych do prywatyzacji, szacowanych na kilka bilionów forintów, podane powyżej kwoty stanowią zaledwie kilka procent majątku prywatyzacyjnego. Trzeba jednak pamiętać, że dla kilkuset tysięcy obywateli węgierskich, proces reprywatyzacji, oprócz wymiaru moralnego, miał wielkie znaczenie finansowe. Osoby te za pomocą bonów, dzięki różnorodnym formom inwestowania, potrafiły nie tylko zaspokoić bieżące potrzeby swoje i rodziny, ale też przyczyniły się do odrodzenia przedsiębiorczości i przyspieszenia wzrostu gospodarczego na Węgrzech ${ }^{24}$. Efekt byłby jeszcze bardziej pozytywny, gdyby większa ilość posiadaczy bonów skorzystała z innej formy ich zainwestowania niż najmniej dochodowe ziemie rolne. Zapewnienie przez państwo odpowiedniej oferty prywatyzacyjnej, skoordynowane z akcją propagandowa, mogłoby wpłynać na zamiary inwestycyjne obywateli, czego efektem mogła być z jednej strony lepsza sytuacja gospodarcza kraju, z drugiej zaś obywatele, którzy objęci zostali programem reprywatyzacji, osiagaliby większe zyski i proces rekompensat byłby przez nich uznawany za bardziej udany.

Ocena programu reprywatyzacji wśród publicystów prawicowych była bardzo surowa. B. Diczhazi pisał: „W przypadku wykorzystania systemu bonów reprywatyzacyjnych największą rolę odgrywały posiadane informacje, znajomości i spekulacje. Osoby mające kontakty w biurach brokerskich odniosły znaczne korzyści przy wymianie bonów na korzystnie sprzedawane akcje, akcje przedsiębiorstw należących do samorządów”,25.

\section{Reprywatyzacja - podsumowanie}

Porównanie węgierskiego programu rekompensat i czechosłowackiej restytucji majątku pokazuje, jak różnie mogą przebiegać zjawiska opisywane wspólnym terminem - reprywatyzacja.

Reprywatyzacja węgierska, choć bez wątpienia była elementem zadośćuczynienia za krzywdy wyrządzone obywatelom w okresie rządów

24 Ibidem, s. 369-370.

25 B. Diczhazi, Przeksztatcenia wtasnościowe na Wegrzech, w: M. Schmidt, L. Gy. Toth (red.), op. cit., s. 98. 
niedemokratycznych, przede wszystkim była sposobem na politycznie i ekonomicznie efektywną prywatyzację państwowego majątku. Decydujące były tu dwa aspekty, właśnie polityczny i ekonomiczny, choć ich siła oddziaływania była mniejsza niż bezpośrednio w przypadku prywatyzacji. Mimo to reprywatyzacja była tym elementem reform, w którym rząd premiera Antalla pokładał duże nadzieje na odniesienie korzyści politycznych i gospodarczych. Na drugim planie pozostał zaś problem zerwania z komunistycznymi ograniczeniami dla własności prywatnej. Inaczej było w Czechosłowacji, gdzie odrzucono model węgierski i skupiono się na możliwe pełnym przywróceniu stanu sprzed 1948 roku. Chociaż przesłanki ekonomiczne i w tym przypadku odgrywały ważną rolę, to głównym celem czeskiej reprywatyzacji było całkowite zerwanie z powszechnym w systemach typu stalinowskiego podejściem do własności prywatnej, przywrócenie jej statusu podstawowej wartości ustrojowej i naprawienie krzywd wyrządzonych przez komunistów w tej sferze ${ }^{26}$.

W tym kontekście zastanawiające jest niepowodzenie wszystkich inicjatyw reprywatyzacyjnych $\mathrm{w}$ Polsce ${ }^{27}$, która stała się jedynym obok Ukrainy i Białorusi, krajem byłego bloku radzieckiego, w którym nie przeprowadzono restytucji majątku. Mimo nacisków międzynarodowych i samych poszkodowanych przez kilkanaście lat, jakie upłynęły od zmiany systemu w Polsce, nie udało się rozwiązać tej podstawowej dla większości krajów reformujących się kwestii. W naszym kraju, w przeciwieństwie do Węgier czy przede wszystkim Czech, reprywatyzacji nigdy nie traktowano jako elementu zerwania z poprzednim systemem, budowy nowego ustroju opartego o własności prywatnej, czy wreszcie jednej z metod wspomagających procesy prywatyzacyjne. W swej niechęci do przeprowadzenia reprywatyzacji politycy różnych opcji powoływali się również na koszty, jakie w związku z tym procesem poniesie budżet państwa, nie próbując jednak dojść do kompromisu z pokrzywdzonymi. Takie opinie prowadziły do negatywnej oceny reprywatyzacji przez większość społeczeństwa, które obawiało się wysokich jej kosztów. Czy w obecnym stanie prawnym i finansowym możliwe jest jeszcze przeprowadzenie pełnej i kompleksowej reprywatyzacji w Polsce? Do pozytywnego rozwiązania tego problemu podochodzić należy z dużym sceptycyzmem.

26 A. Wołek, op. cit., s. 202.

27 Więcej na ten temat: S. Jarosz, Zagadnienia konstytucyjnych podstaw reprywatyzacji, „Państwo i Prawo” 1999, nr 7. 
Najważniejsze zjawiska związane z reprywatyzacją w każdym z prezentowanych krajów przedstawione zostały w poniższej tabeli.

Tabela 1

Polityczny, ideologiczny, ekonomiczny i prawny aspekt reprywatyzacji

\begin{tabular}{|c|c|c|c|c|}
\hline $\begin{array}{l}\text { Aspekt } \\
\text { Kraj }\end{array}$ & Polityczny & Ideologiczny & Ekonomiczny & Prawny \\
\hline Polska & 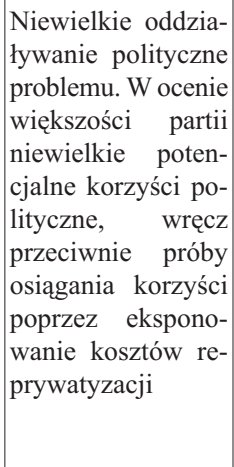 & $\begin{array}{l}\text { W przeciwieństwie } \\
\text { do innych krajów } \\
\text { regionu odrzucenie } \\
\text { reprywatyzacji jako } \\
\text { element przemian } \\
\text { ustrojowych i ze- } \\
\text { rwania zpoprzednim } \\
\text { systemem. Nato- } \\
\text { miast ideologiczny } \\
\text { charakter miało wy- } \\
\text { lączenie z reprywa- } \\
\text { tyzacji osób, które } \\
\text { nie posiadły polskie- } \\
\text { go obywatelstwa }\end{array}$ & $\begin{array}{l}\text { Eksponowano głów- } \\
\text { nie koszty dla bu- } \\
\text { dżetu państwa, po- } \\
\text { mijając korzyści } \\
\text { płynące z przejęcia } \\
\text { często zrujnowanych } \\
\text { majątków przez daw- } \\
\text { nych właścicieli }\end{array}$ & $\begin{array}{l}\text { Powstało kilka pro- } \\
\text { jektów odpowied- } \\
\text { nich ustaw, żadna } \\
\text { z nich nie weszła } \\
\text { w życie. Najbliższy } \\
\text { realizacji był pro- } \\
\text { jekt rządu J. Buzka }\end{array}$ \\
\hline $\begin{array}{l}\text { Czechosło- } \\
\text { wacja }\end{array}$ & $\begin{array}{l}\text { Podobnie jak w Pol- } \\
\text { sce do zwrotu mająt- } \\
\text { ku nie podchodzo- } \\
\text { no z perspektywy } \\
\text { korzyści politycz- } \\
\text { nych, ale wynikało } \\
\text { to z pełnego popar- } \\
\text { ciar wszystkich } \\
\text { znaczących partii } \\
\text { politycznych dla } \\
\text { szybkiego i pełnego } \\
\text { zwrotu majątków }\end{array}$ & $\begin{array}{l}\text { Bardzo silne od- } \\
\text { działywanie ideolo- } \\
\text { giczne. Reprywaty- } \\
\text { zacja była jednym z } \\
\text { głównych filarów } \\
\text { zmian ustrojowych } \\
\text { w państwie i na- } \\
\text { rzędziem szybkie- } \\
\text { go zerwania } \\
\text { przednim po- } \\
\text { mem syste- }\end{array}$ & $\begin{array}{l}\text { Przywoływany } \\
\text { w ograniczonym } \\
\text { zakresie }\end{array}$ & $\begin{array}{l}\text { Uregulowano dwo- } \\
\text { ma ustawami z } 1990 \\
\text { i } 1991 \text { roku }\end{array}$ \\
\hline Węgry & $\begin{array}{l}\text { Ważny element po- } \\
\text { lityczny. Reprywa- } \\
\text { tyzacje traktowano } \\
\text { jako uzupełnienie } \\
\text { programu gospo- } \\
\text { darczego rządu } \\
\text { J. Antalla, część } \\
\text { większego progra- } \\
\text { mu prywatyzacji }\end{array}$ & $\begin{array}{l}\text { Niewielkie znacze- } \\
\text { nie ideologiczne, } \\
\text { kwestia sprawiedli- } \\
\text { wości dziejowej } \\
\text { i zerwania z komu- } \\
\text { nizmem drugopla- } \\
\text { nowa }\end{array}$ & $\begin{array}{l}\text { Ważny element po- } \\
\text { lityki prywatyzacyj- } \\
\text { nej rządu. Rozpa- } \\
\text { trywano również } \\
\text { w kontekście ko- } \\
\text { rzyści ekonomicz- } \\
\text { nych }\end{array}$ & $\begin{array}{l}\text { Uregulowano dwo- } \\
\text { ma ustawami z } 1991 \\
\text { i } 1992 \text { roku }\end{array}$ \\
\hline
\end{tabular}

Źródło: Opracowanie własne.

Znaczenie czynników prezentowanych w tabeli 1 i ich układ hierarchiczny będzie nieco odmienne dla każdego z krajów. W przypadku Polski 
elementem determinującym losy całego procesu będzie aspekt ekonomiczny i koszty całego przedsięwzięcia. W efekcie na dalszy plan zepchnięte zostały polityczne korzyści z reprywatyzacji (brak zainteresowania wykazywały tu wszystkie większe partie polityczne), nie wykorzystano również jej ideologicznego potencjału. Zupełnie inaczej wyglądała sytuacja w Czechosłowacji, gdzie reprywatyzacja stała się jednym z głównych elementów ideologicznych, jakie znalazły się w programach partyjnych. Zgoda wszystkich głównych podmiotów politycznych, co do konieczności szybkiego przeprowadzenia reprywatyzacji i kluczowego jej znaczenia dla procesu reform i zerwania z poprzednim systemem, była tak powszechna, że nikt nie próbował rozgrywać tej kwestii politycznie. Istotne znaczenie miały natomiast kwestie prawne i uznanie ustaw reprywatyzacyjnych za jeden z fundamentów odradzającego się państwa demokratycznego. Wszystko to działo się bez specjalnej troski o ekonomiczny efekt całego procesu i jego koszty dla budżetu. W jeszcze inny sposób można ustalić priorytety polityki reprywatyzacyjnej na Węgrzech. Pierwszoplanową rolę odgrywały tutaj aspekty polityczny i ekonomiczny, na marginesie zainteresowania polityków znalazły zaś się kwestie ideologiczne. Reprywatyzację traktowano na Węgrzech z jednej strony jako ważny element programu partii rządzącej, którego realizacja mogła przynieść jej wymierne korzyści polityczne, z drugiej zaś element szerszego programu prywatyzacyjnego, który może przynieść wymierne korzyści budżetowe.

\section{Summary}

The paper discusses Czech and Hungarian ideas concerning the implementation of the reprivatization program, which are compared with Polish reprivatization programs in the conclusion. In all these countries more or less successful attempts have been undertaken to solve the problem of returning property to former owners. Similar problems have been encountered everywhere, and it has been practically impossble to return to the original status quo. In each country a majority of large industrial plants have expanded. Ater the war numerous state investments carried out which have completely altered these businesses. At the same time, apartments which became state property at some time were being sold on a great scale. 
